科 学 通 报

\title{
连云港西照后沙湾全新世 海滩岩的发现
}

步灾安

(中国科学院地质研究所, 北京 100029)

陈世悦

(中国矿业大学地质系,徐州 221008)

\section{关腱调海滩岩、文石、胶结构}

我国现代和全新世海滩岩常见于西沙群岛和海南岛. 它们现多处于潮间带或潮上带,其 产状与现滩面一致,层理平整,缓缓向海倾斜, 其胶结物主要是在海水条件下形成的文石, 有的 是柱状高镁方解石或高镁方解石泥 ${ }^{[-3]}$. 有些已处于潮上带或陆上的海滩沉积现已被淡水条 件形成的粒状方解石胶结固化, 尽管有的可能早先曾在海底发生胶结, 但已被改造而失去先前 的证据,一般则不称为海滩岩. 这种情况在我国沿海也多处见到 ${ }^{[4,5]}$.

在我国已报道的全新世海滩岩, 最北达浙江象山 ${ }^{[6]}$, 山东乳山的“海滩岩” ${ }^{[n}$ 尚有争议. 目 前, 本文报总的海滩岩成为我国产出最北的.

\section{1 产状与年代}

连云港(新海连市)西墅村西海州湾沿海发育了大片泥质潮坪, 那里是重要的产盐区, 西墅

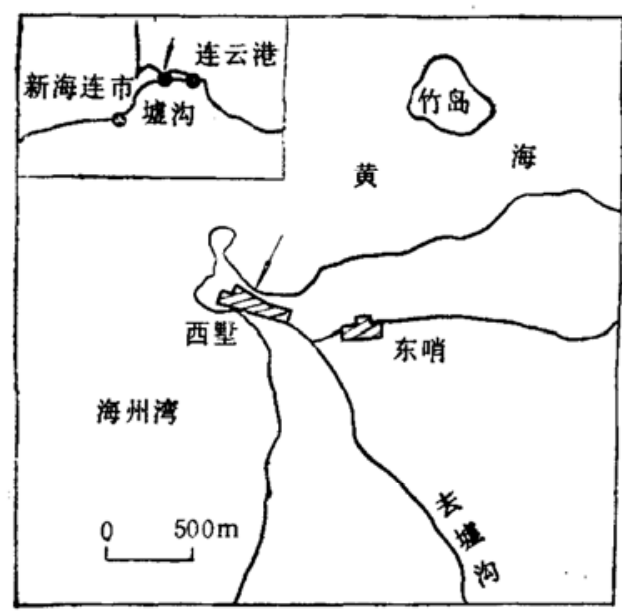

图 1 工作地区位置 箭头 $(\downarrow)$ 指处为海滩岩产地 村北的后沙湾是个宽约 $1 \mathrm{~km}$ 的小海湾(图 1),那 里则是砂质沉积地带. 附近的基岩是元古界云台 组白云斜长片麻岩, 它是砂、砾沉积的主要供应 者.

后沙湾的湾头潮上带部位有一片已胶结固化 的岩石露头, 出露范围大约长 $30 \mathrm{~m}$, 宽 $6 \mathrm{~m}$, 厚约 $65 \mathrm{~cm}$, 单层厚约 $15 \mathrm{~cm}$ (图2 -1). 该岩层层理平 整, 缓缓向海倾斜, 一处见有小型交错层理. 此岩 层之下仍为松散砂砾, 其上覆有零散的砾块. 除 特大潮水外, 此岩层一般不为海水淹没, 即长期暴 露于大气下,并会受到雨水的作用.

以全岩样所测定的 $\mathrm{C}^{14}$ 年龄为距今 $6955 \pm$ $160 \mathrm{a}$, 这可作为参考数据, 因为样品中的汶石质 


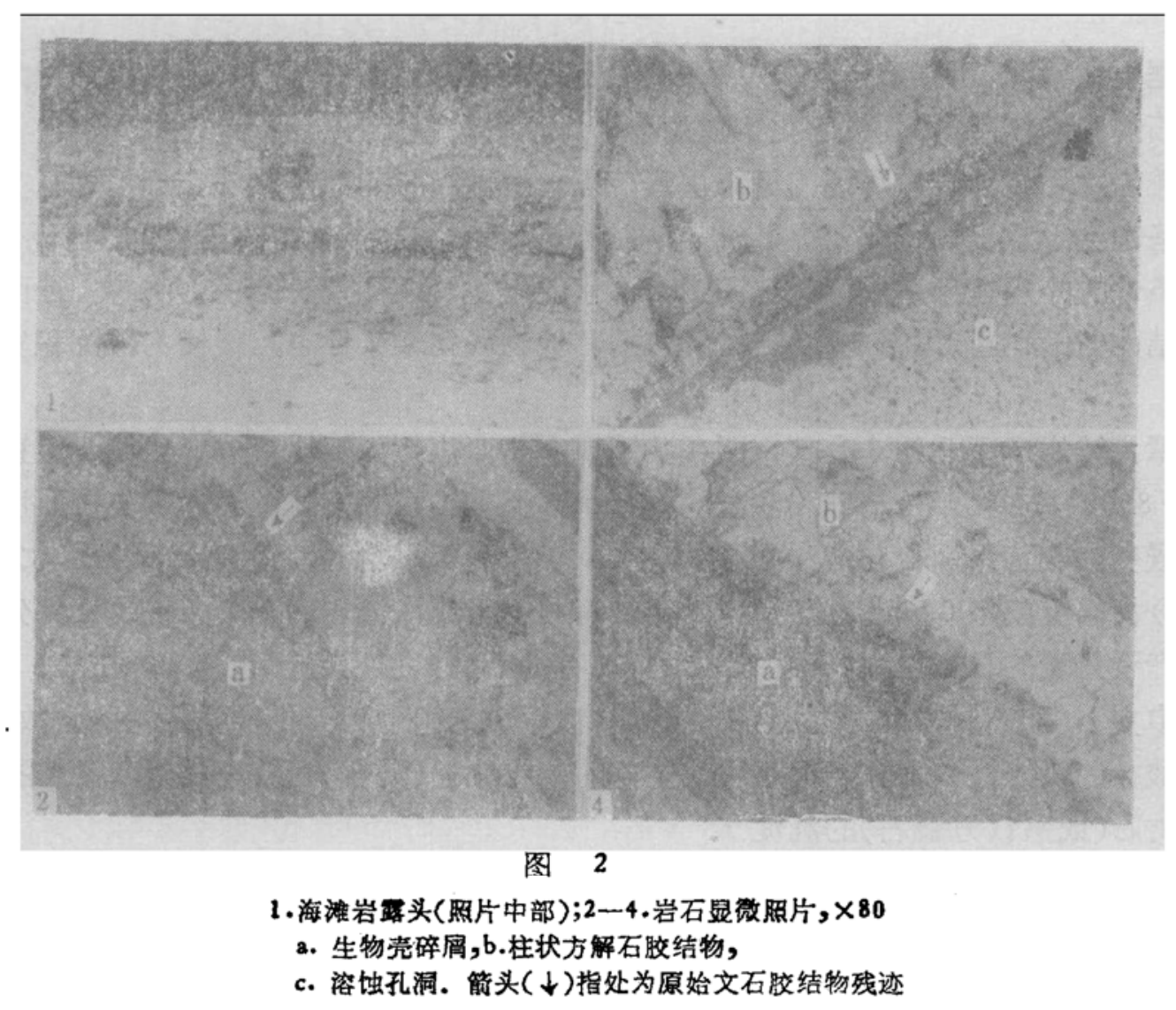

生物壳大部分已转化为方解石, 胶结物亦为后期的粒状方解石. 不过, 结合其产状、岩石学特 征及与其他地区类似沉积比较,无疑当属全新世的产物.

\section{2 岩石学特征}

此海滩沉积为含砾石英一生物粗砂屑灰岩. 其主要组分为生物碎屑和陆源碎肩, 各约占 $50 \%$. 生物碎屏几乎全为软体动物 (主要是瓣鳃类) 碎片, 大小在 $1-2 \mathrm{~mm}$, 磨蚀较重, 多呈长 椭圆状, 壳体有的仍保存为文石(图2-4a), 有的已转化成方解石(图 2-2a), 有的被溶蚀而留下 空洞(图 2-3c).

陆源碎屑主要是(变质)石英, 多呈现波状消光, 另有石英岩碎屑和少许长石碎屑. 颗粒大 小在 $0.05-2 \mathrm{~mm}$ 间, 多为 $0.3-0.75 \mathrm{~mm}$, 次圆状, 分选中等. 岩石中含零星散布的石英或石英 岩砾石,大者可达 $4 \mathrm{~cm}$.

岩石的胶结物主要是粒状方解石,大小在 $0.05-0.75 \mathrm{~mm}$ 间, 也常见有长柱状方解石(图 $2-2 b, 3 b, 4 b$ ), 其长约 $0.05-0.1$. 这种胶结物无疑都是在淡水(雨水)环境条件下的产物.

一个非常关键的、有意义的现象是,在部分碎屑颗粒(可以是生物碎屑或石英砂粒)周边保 存了原始针状文石胶结物的残迹, 它们现被包裹在柱状方解石胶结物中. 在由下而上采集的 五块样品中, 第 2、5 块中比较普遍, 在显微镜下很易识别. 它们垂直于颗粒表面, 其长约 $0.03 \mathrm{~mm}$, 原始文石已不存在, 现留下的痕迹是原文石间呈暗色的杂质(可能为有机物质?)被 包衰在柱状方解石里 (图 2-2-4 箭头所指处). 可以判断, 它们肯定是碎屑颗粒周边的等厚文 石环边胶结物。这同在西沙群岛和海南岛多处所见到的针状文石环边胶结物完全相似。 


\section{3 意义与讨论}

根据上述情况, 可以确定, 西軗后沙湾的这套沉积物当时处于潮间带海水环境条件下已发 生了文石的胶结作用,并固结石化形成海滩岩.

海滩岩除了作为一种可靠的标志用来准确地指示当时的海岸线外,一般认为, 文石胶结的 海滩岩基本上形成于热带和亚热带气候条件下,因而它往往被当成古气候的一个标志。较热 的气候条件的作用在于造成海滩沉积物中海水的较强蒸发而使 $\mathrm{CO}_{2}$ 较快散失, 进而促进碳酸 钻较快结晶,在颗粒周围形成胶结物. 不过,其他物理化学条件也可促使海滩沉积发生胶结作 用.

西照海滩岩产于北纬 $34^{\circ} 45^{\prime}$, 即在我国现今北亚热带与暖温带分界线稍北位置. 资料表 明,距今 8000-2500 年是全球和我国的全新世高温期. 在邻近建湖县的庆丰剖面所建立的全 新世气候变化与海平面变化曲线中,距今 6900 年前后年平均温度约高于现今 $1.2{ }^{\circ} \mathrm{C}$, 当时海面 约在现今海面上或下 $0.5 \mathrm{~m}^{\mathrm{n} 3}$. 这或许是当时有利于形成海滩岩的一个条件. 世界分布最北的 海滩岩产于丹麦的日德兰半盘西海岸(卡特加特海沿岸), 那里位于北纬 $55^{\circ}$ 左右. 对于那里 海滩岩中文石(和离镁方解石)胶结物的形成,被解释是由于物理化学条件特殊之故. 即陆上 富重碳酸盐的淡水注入海滩与沉积物最上部的海水相遇(混合), 并在相对封闭的孔隙环境里 发生了文石(或富镁方解石)的沉淀 ${ }^{[9]}$.

西照海滩岩胶结作用的发生极有可能与上述丹麦海滩岩的情况类似. 只是因为它的文石 胶结物已转化为方解石而难于取得地球化学方面的数据. 进一步的研究尚待进行.

致濑野外工作得到中国矿业大学地质系刘焕杰教授、贾如玉教授的帮助; 中国科学院 地质研究所赵希涛副研究员对一些问题进行了讨论, 桂文立、张亚光协助制作照片, 国家地震 局地质研究所碳十四实验室测定 $\mathrm{C}^{14}$ 年龄,在此一并表示感谢.

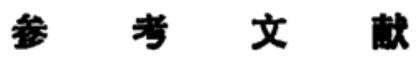

[1] 黄金森等,地质科学, $1978,(4): 358-364$ 。

[2] 影希涛等,地质科学, $1978,(2): 163-173$.

[3] 沙庆安等,沉积岩石学论文集, 1981,226-242。

[4] 沙庆安,沉积学报, 1986,4(2): 39-46.

[5] 沙庆安,海洋学报, 1989,11(1): 122-126.

[6] 高中和等,地震地质, 1991,13(1): 28-32.

[7] 林宝荣,海洋地质与第四纪地质, 1985,5(4): 58.

[8] 赵希涛,中图科学, B 辑, 1991,(9): 992-999.

[9] J中rgensen, N.O., J.Sediment. Petrol., 1976,45: 940-951. 